\title{
PURIFICATION AND CHARACTERIZATION OF EXTRACELLULAR LIPASE FROM A NEW STRAIN - PSEUDOMONAS AERUGINOSA SRT 9
}

\author{
Prita S. Borkar ${ }^{1,2 *}$; Ragini G. Bodade²; Srinivasa R. Rao²; Khobragade C.N. ${ }^{2}$ \\ ${ }^{1}$ Department of Microbiology, N.E.S. Science college, Nanded - 431 605, India; ${ }^{2}$ School of Life Sciences, Biotechnology \\ Research Laboratory, Swami Ramanand Teerth Marathwada University, Nanded - 431 606, India
}

Submitted: June 10, 2008; Returned to authors for corrections: September 29, 2008; Approved: March 31, 2009.

\begin{abstract}
An extra cellular lipase was isolated and purified from the culture broth of Pseudomonas aeruginosa SRT 9 to apparent homogeneity using ammonium sulfate precipitation followed by chromatographic techniques on phenyl Sepharose CL- 4B and Mono Q HR 5/5 column, resulting in a purification factor of 98 fold with specific activity of $12307.8 \mathrm{U} / \mathrm{mg}$. The molecular weight of the purified lipase was estimated by SDS-PAGE to be $29 \mathrm{kDa}$ with isoelectric point of 4.5. Maximum lipase activity was observed in a wide range of temperature and $\mathrm{pH}$ values with optimum temperature of $55^{\circ} \mathrm{C}$ and $\mathrm{pH}$ 6.9. The lipase preferably acted on triacylglycerols of long chain (C14-C16) fatty acids. The lipase was inhibited strongly by EDTA suggesting the enzyme might be metalloprotein. SDS and metal ions such as $\mathrm{Hg}^{2+}, \mathrm{Zn}^{2+}, \mathrm{Cu}^{2+}, \mathrm{Ag}^{2+}$ and $\mathrm{Fe}^{2+}$ decreased the lipase activity remarkedly. Its marked stability and activity in organic solvents suggest that this lipase is highly suitable as a biotechnological tool with a variety of applications including organo synthetic reactions and preparation of enantiomerically pure pharmaceuticals. The Km and Vmax value of the purified enzyme for triolein hydrolysis were calculated to be $1.11 \mathrm{mmol} / \mathrm{L}$ and $0.05 \mathrm{mmol} / \mathrm{L} / \mathrm{min}$ respectively.
\end{abstract}

Key words: Pseudomonas aeruginosa SRT9, extra cellular lipases, purification, Michaelis constant

\section{INTRODUCTION}

Lipases are glycerol ester hydrolases (EC 3.1.1.3), which hydrolyze ester linkages of glycerides at water-oil interface $(5,34,44)$. An important characteristic of lipases is their ability not only to hydrolyze the ester bonds, trans-esterify triglycerides and resolve racemic mixture, but also to synthesize ester bonds in non-aqueous media $(21,29)$. It is well known that lipases are the most widely used enzymes in organic synthesis and more than $20 \%$ biotransformations are performed with lipases (12). To date, a large number of lipases from bacteria and fungi have been extensively studied, both from the biochemical and from the genetic point of view $(3,38,41)$. The most productive species belongs to genera Geotrichum, Penicillium, Aspergillus and Rhizomисоr $(30,39)$. Lipases from unicellular, mainly those produced by various species of genus Pseudomonas, have been proved to be useful both in organic reactions and in the detergent industry (17). Most of the well-studied microbial lipases are inducible extra cellular enzymes. They are synthesized within the cell and exported to its external surface or environment $(40,41,45)$. Many of them have been purified, characterized and their encoding genes cloned $(35,37,40)$.

Microbial lipases constitute an important group of biotechnologically valuable enzymes, mainly because of versatility of their applied properties and ease of mass production $(13,28,42)$. Besides their industrial applications, novel biotechnological applications have been successfully established using lipases for the synthesis of biopolymers and biodiesel, the production of enantiopure pharmaceuticals, agrochemicals and flavor compounds (16). Because of huge variation in applications, the availability of lipases with specific characteristics is still a limiting factor. Thus, to search for new lipases with different characteristics continue to be important research topics.

*Corresponding Author. Mailing address: Department of Microbiology, N.E.S. Science college, Nanded - 431 605, India. Phone: +91 2462 256804 ; Fax: +91 2462 229245/229325. E-mail: prita_chaware@yahoo.com 
In this work, we describe the production, purification and some remarkable properties of the lipase of this bacterium. Several features of the lipase regarding its substrate specificity, behavior in organic solvent, thermo stability have been reported.

\section{MATERIALS AND METHODS}

Pseudomonas aeruginosa sp. was isolated from oil and petroleum spilled soil and maintained on a growth medium containing g/L: Beef extract 1.0, Yeast extract 2.0, Peptone 5.0, $\mathrm{NaCl} 5.0$, Agar $15, \mathrm{pH} 7 \pm 0.2$ at $4^{\circ} \mathrm{C}$. The culture was periodically subcultured. For inoculum preparation the culture was reactivated by transferring into fresh broth medium containing olive oil ( $1 \% \mathrm{w} / \mathrm{v})$ as inducer and incubated $30^{\circ} \mathrm{C}$ for $24 \mathrm{~h}$.

Extra cellular lipase producing Pseudomonas aeruginosa SRT 9 (a high lipase producing strain) was identified based on cell morphology, cultural and biochemical characteristics. Further, it was confirmed by $16 \mathrm{~S}$ rDNA technique. The sequence was edited and aligned with the sequence in the public domain Gen bank (http://www.ncbi.nih.gov) by BLAST program (4) and the organism was granted a genus and a species.

\section{Lipase production}

Production medium was prepared containing g/L: Peptone 5.0. Yeast extract 10.0, $\mathrm{NaCl} 5.0$ and olive oil $(1 \% \mathrm{w} / \mathrm{v})$ as inducer. The initial $\mathrm{pH}$ of the medium was adjusted to 7.0. In Erlenmeyer flasks $(500 \mathrm{ml})$ containing $100 \mathrm{ml}$ of production medium, inoculum culture $(1 \% \mathrm{w} / \mathrm{v})$ was added and gently swirled. The inoculated flasks were incubated at $30^{\circ} \mathrm{C}$ on a rotary shaker at $220 \mathrm{rpm}$ for $48 \mathrm{~h}$.

\section{Lipase activity}

Lipase activity was determined titrimetrically using olive oil hydrolysis (27). $1 \mathrm{ml}$ enzyme solution was added to the assay substrate containing $10 \mathrm{ml}$ of $10 \%$ homogenized olive oil in $10 \%$ gum acacia, $2 \mathrm{ml}$ of $0.6 \% \mathrm{CaCl}_{2}$ solution and $5 \mathrm{ml}$ of $0.2 \mathrm{~mol} / \mathrm{L}$ Phosphate buffer, $\mathrm{pH}$ 7.0.The enzyme - substrate was incubated on orbital shaker at $150 \mathrm{rpm}$ at $30^{\circ} \mathrm{C}$ for $1 \mathrm{~h} .20 \mathrm{ml}$ ethanol-acetone (1:1) was added to stop the reaction. Liberated fatty acids were titrated with $0.1 \mathrm{~mol} / \mathrm{L} \mathrm{NaOH}$ using phenolphthalein as indicator. The reaction mixture without the enzyme was titrated in the same way and used as blank. One 'lipase unit' was defined as the amount of the enzyme that released one $\mu$ mol fatty acid per min under standard assay conditions.

Lipase activity was measured spectrophotometrically (410 $\mathrm{nm}, \mathrm{pH}$ 7.0) using p-nitro phenyl palmitate (pNPP) as described by Winkler and Stuckmann (45). One unit of lipase activity was defined as the amount of enzyme that liberated $1 \mu$ mol of p-nitro phenol from pNPP per min under the assay condition.

\section{Purification of lipase}

After the incubation period, the culture was centrifuged at $15,000 \mathrm{rpm}$ for $20 \mathrm{~min}$ at $4^{\circ} \mathrm{C}$. An enzyme preparation was obtained by precipitation with $30-90 \%$ ammonium sulphate fractionation. The precipitates were dissolved in $5 \mathrm{ml}$ of Tris- $\mathrm{HCl}$ buffer $(\mathrm{pH}$ 6.8 ) and dialyzed overnight against $2 \mathrm{~L}$ of the same buffer. Each fraction was checked for enzyme activity as well as protein content. 30\% ammonium sulphate fraction showing maximum lipase activity was mixed with ammonium sulphate to a final concentration of $0.25 \mathrm{M}$ in $50 \mathrm{mM}$ Tris-HCL buffer, $\mathrm{pH} 6.8$ and applied to $15 \mathrm{ml}$ of preactivated phenyl Sepharose CL-4B (1.5 $\mathrm{X} 24 \mathrm{~cm}$ ). The enzyme was eluted with linear gradient of $1 \%(\mathrm{w} /$ v) cholate in $50 \mathrm{mM}$ Tris-HCl buffer, $\mathrm{pH} 6.8$ with flow rate of $1 \mathrm{ml} /$ min. All the fractions were checked for enzyme activity. The active fractions were pooled and applied on pre-equilibrated Mono Q HR5/5 Column (1X6cm). The enzyme was eluted by gradient $\mathrm{NaCl}(0-1.0 \mathrm{M})$ in the same buffer at a flow rate of $1 \mathrm{ml} /$ $\min$. The active fractions that contained lipase enzyme were pooled, desalted and rechromatographed on Mono Q HR5/5 Column $(1 \mathrm{X} 6 \mathrm{~cm})$. The enzyme was eluted with linear gradient of $\mathrm{NaCl}(0-0.5 \mathrm{M})$ in the same buffer at a flow rate of $0.5 \mathrm{ml} / \mathrm{min}$. The lipase containing fractions were pooled and assessed for protein content. The resulting enzyme was utilized for the characterization of the extracellular lipase.

The protein content at each stage of enzyme purification was determined accordingly to Lowry et al (26) with Bovine serum albumin as the standard.

\section{SDS-PAGE}

The enzyme was electrophoresed on a $10 \%$ native polyacrylamide gel according to standard procedures (23) using a standard protein markers $\alpha$-Lactalbumin (14.3kDa), Trypsin inhibitor (20.1kDa) Carbonic anhydrase (29kDa), Ovalbumin $(43 \mathrm{kDa})$ Bovine serum albumin $(66 \mathrm{kDa})$ and Phosphorylase B $(97.4 \mathrm{kDa})$.

\section{Zymogram}

Zymogram study was carried according to the method proposed by Gabriel (2). Zymogram solution A contained $20 \mathrm{mg}$ of $\alpha$-naphthyl acetate dissolved in $5 \mathrm{ml}$ of acetone to which 45 $\mathrm{ml}$ of $100 \mathrm{mM}$ potassium phosphate buffer $(\mathrm{pH} 7)$ was added while stirring. Solution B contained $50 \mathrm{mg}$ of Fast Red TR -salt in $50 \mathrm{ml}$ of the same buffer. The solutions were prepared freshly and mixed 1:1 prior to use. The gels was incubated in the reaction mixture on a gel shaker for 5 to $15 \mathrm{~min}$, on esterase activity, redness due to formation a complex between the naphthyl residue and fast red develops.

\section{Determination of Isoelectric point}

Isoelectric focusing (IEF) was carried out by IPG (immobilized $\mathrm{pH}$ gradient) strips with non-linear separation range of 3-10 (Amersham Bioscience) according to manufacture's instruction. Enzyme was detected using standard Commassie B staining and isoelectric point was determined according to calibrating curve supplied by the manufacturer. 


\section{Determination of Temperature and pH optima}

The temperature and $\mathrm{pH}$ optimum of extra cellular lipase was determined at different temperatures ranging from $30-80^{\circ} \mathrm{C}$ and $\mathrm{pH}$ values from 6 to 10.0. To determine the effect of temperature on lipase activity, purified enzyme and substrate were incubated at various reaction temperatures before starting the experiment and the enzyme assay was performed to determine the optimal temperature titrimetrically using olive oil as substrate.

The optimal $\mathrm{pH}$ was determined by incubating the enzymesubstrate at various $\mathrm{pH}$ from 3 to 10 using different buffers Sodium citrate (5-6), potassium phosphate (6-8), Tris HCL (7-9), Glycine $\mathrm{NaOH}(9-10)$.

\section{Thermo stability and pH stability of lipase}

Thermo stability of the enzyme was determined by incubating purified enzyme for $30 \mathrm{~min}$ in $50 \mathrm{mM}$ Tris-HCL buffer (pH 6.8) at different temperatures $\left(30-80^{\circ} \mathrm{C}\right)$. The residual lipolytic activities were then determined using olive oil as substrate.

For $\mathrm{pH}$ stability, purified enzymes were incubated using different $\mathrm{pH}$ buffers. The reaction mixtures were incubated as per standard assay and the residual lipolytic activities were then determined using olive oil as substrate.

\section{Substrate specificity}

The activities of the enzyme toward various triglycerides and natural oils were investigated. Lipase activity was measured by the alkaline titration method (19). A solution was prepared by mixing $10 \mathrm{ml}$ of $5 \%$ (v/v) substrate (with $1 \%$ gum arabic) 10 $\mathrm{ml}$ of $50 \mathrm{mM}$ Tris-HCL buffer supplemented with $40 \mathrm{mM}$ sodium chloride ( $\mathrm{pH} 9.0$ ), $2.0 \mathrm{ml}$ of sodium deoxycholate solution (80 $\mathrm{mg} / \mathrm{ml} \mathrm{pH} \mathrm{9.0)} \mathrm{and} 1 \mathrm{ml}$ of purified enzyme in Tris-HCL buffer (pH 6.8). After adjusting $\mathrm{pH}$ to 9.0, the reaction was carried out at $55^{\circ} \mathrm{C}$ for $1 \mathrm{~h}$ with stirring at $150 \mathrm{rpm}$ on a rotary shaker. Fatty acids liberated during incubation were titrated by $0.05 \mathrm{M} \mathrm{NaOH}$ to $\mathrm{pH} 9.0$ One unit (1U) is that quantity that liberates $1 \mu \mathrm{mol}$ of acid / min under standard assay conditions. Enzymatic activity against triolein was defined as $100 \%$.

Substrate preference towards p-nitro phenyl fatty acyl esters was determined spectrophotometrically under standard assay conditions. The results were expressed as a percentage of the substrate that gave maximal activity.

\section{Effect of inhibitors / activators on lipase activity}

The effects of different inhibitors, salts on lipase activity were examined by measuring remaining activity after incubation with $5 \mathrm{mM}$ EDTA and $2 \mathrm{mM}$ concentrations of other inhibitors and salts at $30^{\circ} \mathrm{C}$ for $30 \mathrm{~min}(\mathrm{pH} \mathrm{7.0)}$ under standard assay conditions.

\section{Effect of detergent and metal ions on lipase activity}

For determining the effect of detergents and metal ions on lipase activity, the purified enzyme were preincubated with $1 \mathrm{mM}$ for $30 \mathrm{~min}$ at $30^{\circ} \mathrm{C}$ and the residual activity was determined using olive as substrate under standard assay conditions.

\section{Stability and activity in organic solvent}

The enzyme solution was mixed with different solvent solutions to yield the desired final solvent concentrations (20 $\& 30 \%$ ). The solvents used were acetone, methanol, ethanol, iso-propanol, butanol, n-Hexane. An enzyme sample was exposed to solvents for 1 and $24 \mathrm{~h}$ at $30^{\circ} \mathrm{C}$ after which its residual enzyme activity was measured using p- NPP as substrate under standard assay conditions.

\section{Kinetic constants}

The influence of substrate concentration on the reaction velocities of the purified lipase was studied with triolein as triglyceride substrate and p-NPL and p-NPP among the p-nitro phenyl esters. The purified lipase was incubated with various concentration of emulsified triolein. The final concentration ranged from $0.5 \mathrm{mmol} / \mathrm{L}$. For p-nitrophenylesters the final concentration ranged from $10-80 \mathrm{mmol} / \mathrm{L}$. In all cases, the enzymatic activity was assayed under temperature and $\mathrm{pH}$ optima. The Michaelis constant $(\mathrm{Km})$ and maximum velocity (Vmax) was determined from Lineweaver-Burk plots.

The residual activity was determined titrimetrically using olive oil as substrate using standard method. Each value in all the above experiments is the mean of triplicate experiments.

\section{RESULTS AND DISCUSSION}

\section{Purification of Lipase}

In the present work lipase produced by Pseudomonas aeruginosa SRT 9 in the culture broth was subjected to a purification protocol. The purification involved ammonium sulphate fractionation followed by phenyl Sepharose CL- 4B and Mono Q HR 5/5 column chromatography steps (Table 1).

The ammonium sulphate $(30 \%)$ fraction was applied to FPLC phenyl Sepharose CL-4B column. Many protein peaks were observed and only one activity peak was detected (fractions 13-17). Active fractions were pooled and applied on Mono Q HR 5/5 column and the eluted enzyme showed activity peak in fraction numbers 3-4. The active fractions were again pooled, desalted and applied on the Mono Q HR 5/5 column and eluted by gradient $\mathrm{NaCl}$. The fraction numbers 3-4 coincided with lipase activity peak (Fig. 1A, B). The purification process resulted in 98- fold purification factor and a final recovery (yield) of $7.53 \%$ of the enzyme with specific activity of $12307.81 \mathrm{U} / \mathrm{mg}$.

The molecular mass was estimated to be $29 \mathrm{kDa}$ (Fig. 2) with isoelectric point of 4.5 and Zymogram study revealed ester hydrolase activity. Many lipases from Pseudomonas sp. had a molecular mass of 29-30 kDa with pI 4.5-5.8 (7,8,36,40). 
Table 1. Purification summary of lipase from Ps. aeruginosa SRT9.

\begin{tabular}{cccccc}
\hline Purification steps & $\begin{array}{c}\text { Total protein } \\
(\mathrm{mg})\end{array}$ & $\begin{array}{c}\text { Total activity } \\
(\mathrm{U})\end{array}$ & $\begin{array}{c}\text { Specific activity } \\
(\mathrm{U} / \mathrm{mg})\end{array}$ & $\begin{array}{c}\text { Purification } \\
(\text { fold })\end{array}$ & $\begin{array}{c}\text { Yield } \\
(\%)\end{array}$ \\
\hline Culture filtrate & 884 & 111024 & 125.59 & 1 & 100 \\
Ammonium sulphate & 5.59 & 14635.05 & 2618.07 & 20.84 & 13.18 \\
phenyl Sepharose CL-4B & 2.94 & 13353.02 & 4541.84 & 36.16 & 12.02 \\
Mono Q column & 0.68 & 8369.31 & 12307.81 & 98 & 7.53 \\
\hline
\end{tabular}
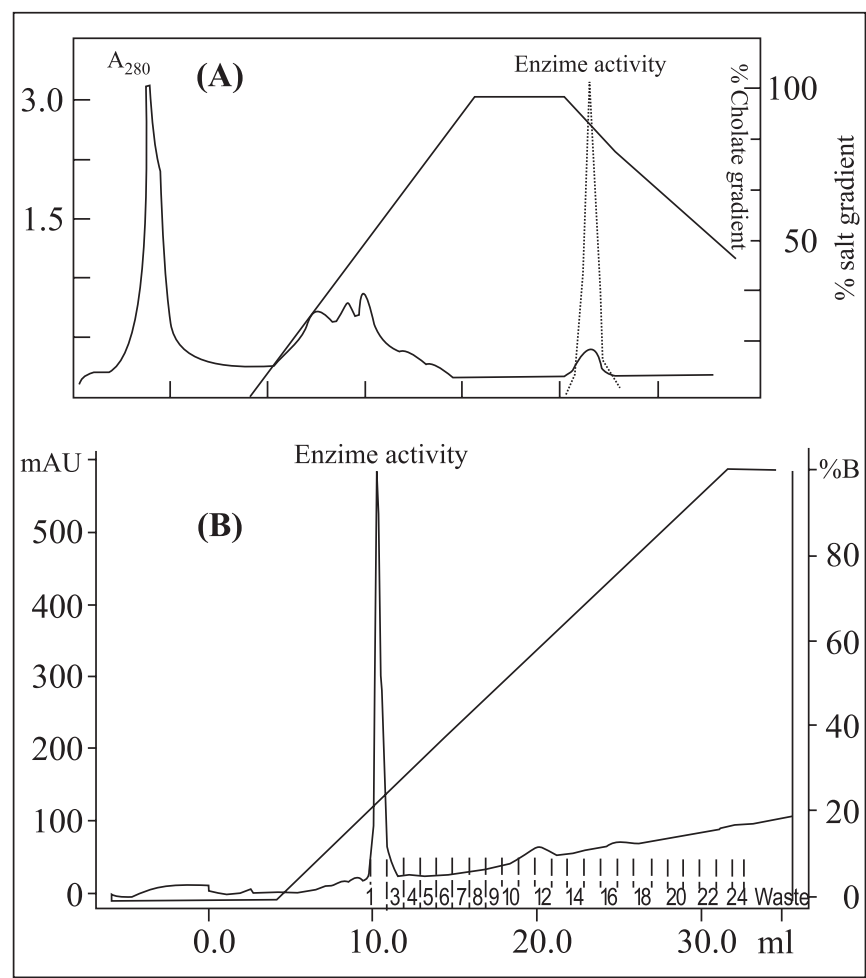

Figure 1. Elution profile of Pseudomonas aeruginosa SRT 9 lipase. Figure 1A: Chromatograph of partially purified $P s$. aeruginosa SRT 9 lipase on FPLC with phenyl Sepharose column Figure 1B: FPLC profile of active fraction of Ps. aeruginosa lipase from Mono Q on Mono Q column.

\section{Optimal Activity}

The purified enzyme exhibited maximal activity at $55^{\circ} \mathrm{C}$ temperature and $\mathrm{pH}$ 6.9. The enzyme was found to be fairly stable up to $65^{\circ} \mathrm{C}$, however when the upper limit was approached, the activity diminished indicating thermal denaturation (Fig. 3). The enzyme was remarkably stable in the $\mathrm{pH}$ range $6-7.5$ retaining more than $68 \%$ of the residual activity at $\mathrm{pH} 8$ (Fig. 4). This enzyme showed to be more stable at high temperature and $\mathrm{pH}$ as compared to lipase obtained from Pseudomonas aeruginosa $\mathrm{EF} 2\left(50^{\circ} \mathrm{C}\right.$ and $\mathrm{pH}$ range 6.5-7.5) (11).

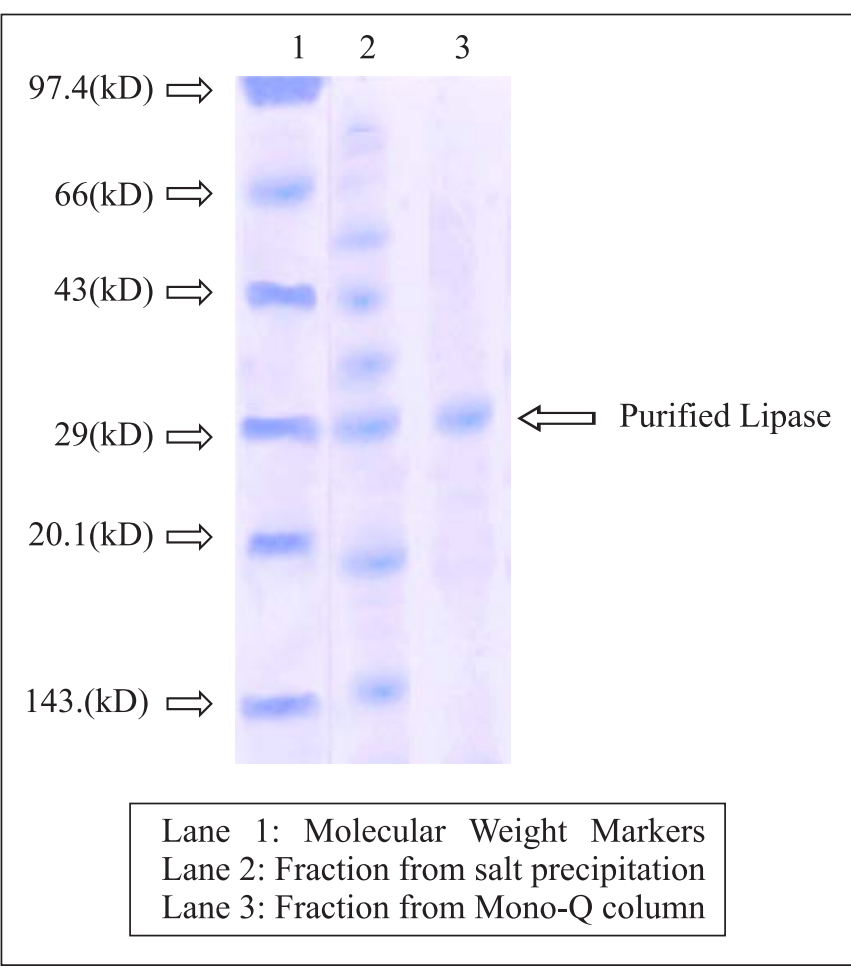

Figure 2. SDS - PAGE of Pseudomonas aeruginosa SRT 9 lipase purification steps.

\section{Thermal stability}

The thermal stability of purified lipase was investigated at various temperatures ranging from $50-80^{\circ} \mathrm{C}$ (Fig. 5). The enzyme was found to be completely stable at $55^{\circ} \mathrm{C}$ after $2 \mathrm{~h}$. At $65^{\circ} \mathrm{C}$, the enzyme maintained $78 \%$ of the initial activity after $1 \mathrm{~h}$ and $46 \%$ activity after $2 \mathrm{~h}$, presenting a half-life of $102 \mathrm{~min}$. The half-life of this enzyme at $70^{\circ} \mathrm{C}$ was $50 \mathrm{~min}$. The results showed that this enzyme is more stable than lipases obtained from Pseudomonas pseudoakaligenes F-111 and Pseudomonas Ps-x, which showed stability upto only $70^{\circ} \mathrm{C}(25,33)$.

\section{Effect of inhibitors/activators}

Lipase activity was assayed in the presence of various inhibitors and activators. The results showed that enzyme 


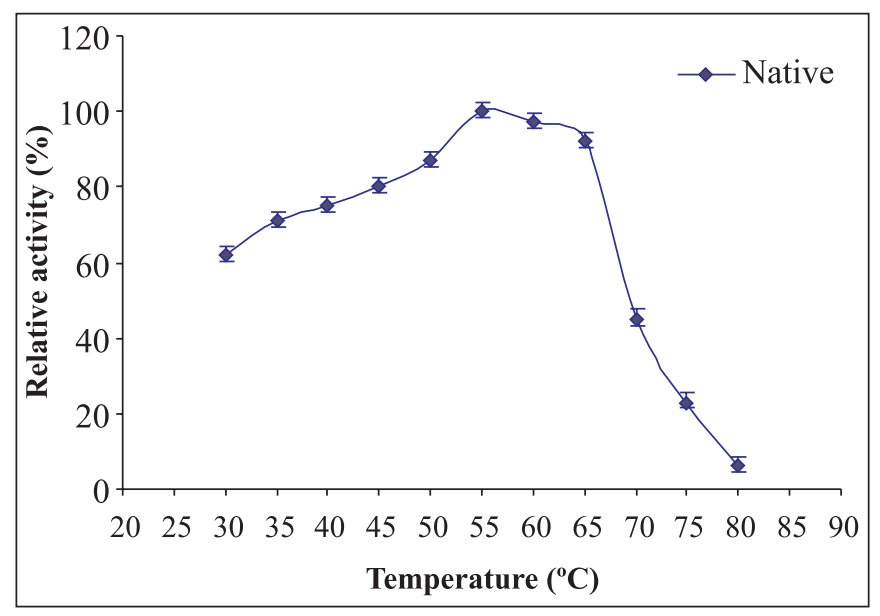

Figure 3. Effect of Temperature on Pseudomonas aeruginosa SRT 9 Lipase.

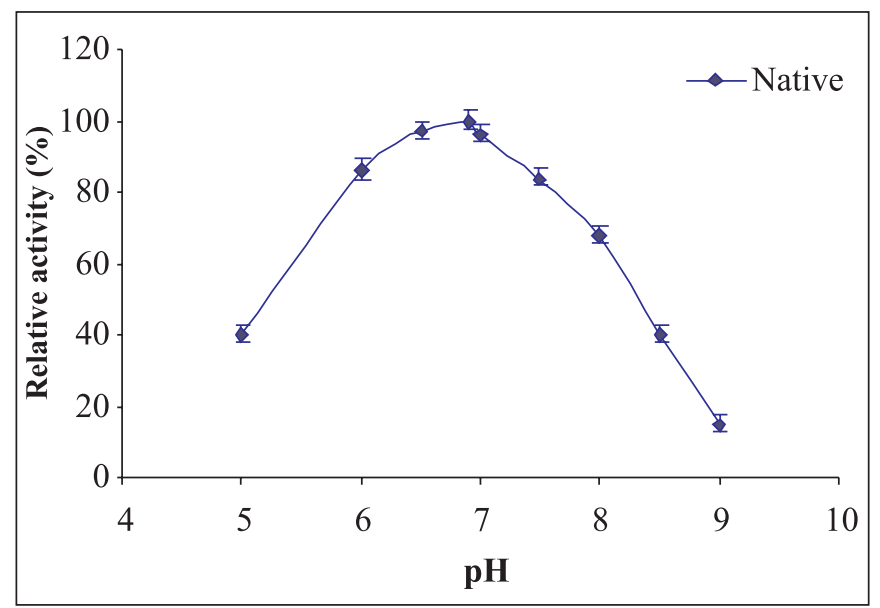

Figure 4. Effect of $\mathrm{pH}$ on Pseudomonas aeruginosa SRT 9 Lipase.

activity was decreased considerably in presence of $5 \mathrm{mM}$ EDTA with only $36 \%$ residual activity left at $30^{\circ} \mathrm{C}$ after 30 min incubation, indicating that the enzyme might be metalloprotein (9). The reducing agent, $\beta$ mercaptoethanol $(2 \mathrm{mM})$ and sulphydrylreactive reagent dimethylformamide $(2 \mathrm{mM})$ showed remarkable inhibitory effect with 87 and $85 \%$ residual activities respectively, indicating that the presence of - SH groups are essential for enzymatic activity (2).

Among the metal ions tested, enhancement in the enzyme activity was observed in presence of $\mathrm{Ca}^{2+}$ with $122 \%$ relative activity when compared to control (Table 2). Lipase enzyme have been found to be $\mathrm{Ca}^{2+}$ dependent and also showed increase in the thermo stability (Fig. 6). The enzyme, having lost its

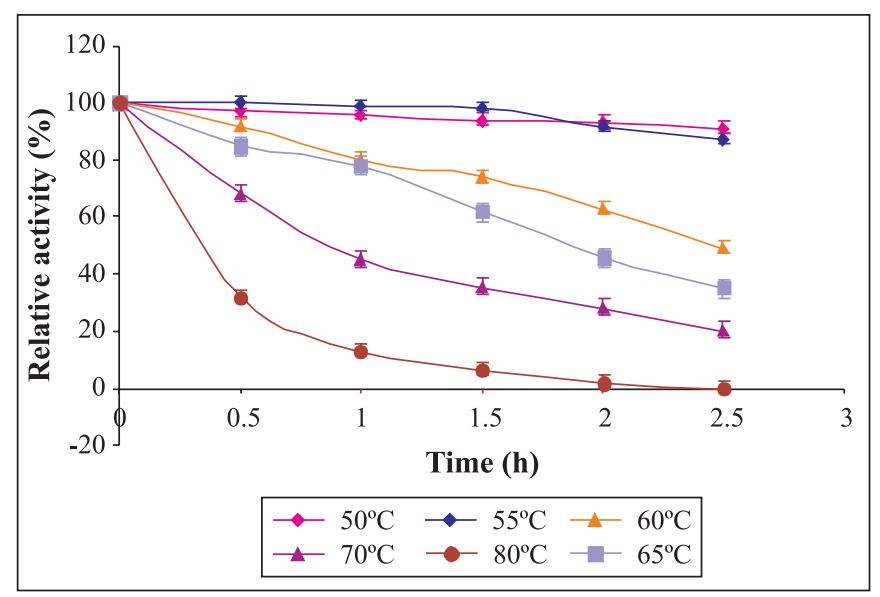

Figure 5. Effect of Temperature on lipase stability.

Table 2. Effect of different inhibitors/activators on enzyme activity.

\begin{tabular}{clcc}
\hline \multirow{2}{*}{ Inhibitors } & Reagents & $\begin{array}{c}\text { Conc. used } \\
(\mathrm{mM})\end{array}$ & $\begin{array}{c}\text { Remaining } \\
\text { activity }(\%)\end{array}$ \\
\hline \multirow{6}{*}{ Salts } & EDTA & 5.0 & 36 \\
& DMSO & 2.0 & 89 \\
& $\beta-$ Dercaptoethanol & 2.0 & 87 \\
& Dimethyl formamide & 2.0 & 85 \\
\hline \multirow{6}{*}{} & $\mathrm{NaCl}$ & 2.0 & 105 \\
& $\mathrm{CaCl}_{2}$ & 2.0 & 122 \\
& $\mathrm{MgCl}_{2}$ & 2.0 & 103 \\
\hline
\end{tabular}

activity in presence of EDTA could be reactivated by the addition of $\mathrm{CaCl}_{2}$ and there was increase in thermo stability of the lipase by about 10 degrees in comparison with lipase from Bacillus stearothermophillus (about 8-10 degrees) (20). Some lipases produced by Pseudomonas sp. have been found to be $\mathrm{Ca}^{2+}$ dependent, however $\mathrm{Ca}^{2+}$ exerted inhibitory effect on Pseudomonas sp. Strain S5 (32).

The effect of different detergents on the lipase activity indicated that the enzyme was fairly stable to non-ionic detergents like Tween-20, -40 and -80 . Instead lipase activity was enhanced initially on their addition ( $\sim 3 \%$ increase). Triton $\mathrm{X}-100$ resulted in $10 \%$ decrease in the activity within $30 \mathrm{~min}$. Treatment of ionic detergents like SDS resulted in remarkable loss of enzymatic activity (Table 3). SDS was also reported to be a strong inhibitor of Bacillus thermoleovorans CCR11 lipases and Fusarium oxysporum lipases causing almost total inhibition of enzyme activity $(6,18)$. Non-ionic detergents seem to weaken the hydrophobic interaction within the protein causing disaggregation and thus stabilizing its activity while 


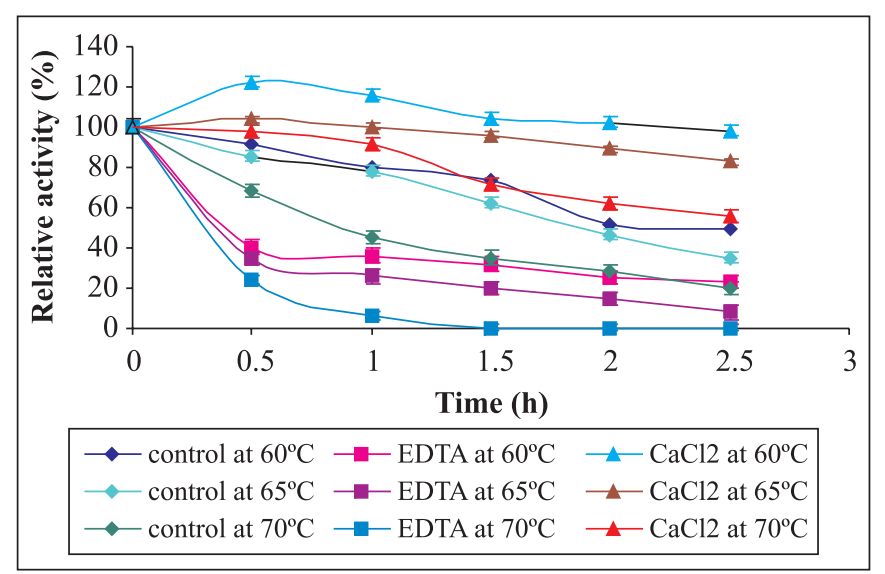

Figure 6. Effect of $\mathrm{CaCl} 2$ and EDTA on thermostability of lipase enzyme.

Table 3. Effect of different detergents on enzyme activity.

\begin{tabular}{ccccc}
\hline \multirow{5}{*}{ Surfactants } & Compounds & $\begin{array}{c}\text { Conc. used } \\
\%(\mathrm{w} / \mathrm{v})\end{array}$ & \multicolumn{2}{c}{$\begin{array}{c}\text { Remaining } \\
\text { activity }(\%)\end{array}$} \\
\cline { 3 - 5 } & & & $0.5 \mathrm{~h}$ & $1 \mathrm{~h}$ \\
\hline \multirow{5}{*}{ SDS } & 1.0 & 29.0 & 3.0 \\
& Tween-20 & 1.0 & 104.5 & 101.0 \\
& Tween-40 & 1.0 & 103.0 & 100.5 \\
& Tween-60 & 1.0 & 90.0 & 84.0 \\
& Tween-80 & 1.0 & 104.5 & 102.0 \\
Triton X-100 & 1.0 & 91.0 & 70.0 \\
$\begin{array}{c}\text { Sodium- } \\
\text { deoxycholate }\end{array}$ & 10.0 & 99.9 & 97.5 \\
\hline
\end{tabular}

SDS acts upon the di-sulphide linkages and causes inactivation/ denaturation of protein (24).

The effect of mono and divalent cations on the enzyme activity was assessed at $1 \mathrm{mM}$ concentration. $\mathrm{Ca}^{2+}$ showed stimulatory effect whereas $\mathrm{Mg}^{2+}, \mathrm{Mn}^{2+}, \mathrm{Ba}^{2+}$ had negligible effect on the enzyme activity with $\sim 97 \%$ relative activity. However $\mathrm{Hg}^{2+}$ and $\mathrm{Pb}^{2+}$ inhibited the enzyme activity by about $35 \%$. $\mathrm{Ag}^{2+}$, $\mathrm{Fe}^{2+}, \mathrm{Cu}^{2+}$ and $\mathrm{Zn}^{2+}$ reduced enzyme activity to less than $37 \%$ of its relative activity (Table 4). Lipases from thermophilic Rhizopus oryzae and Mucor sp. isolated from palm fruit showed very depressed activity in the presence of $\mathrm{Hg}^{2+}, \mathrm{Fe}^{3+}, \mathrm{Fe}^{2+}$ and $\mathrm{Cu}^{2+}$ with respect to our lipases $(1,15)$.

\section{Effect of organic solvents on lipase activity}

Stability and activity of enzyme in organic solvents depend not only on the properties and concentration of the organic solvent, but also on the nature of the enzymes (43). Enzyme, being proteins, lose their activity after addition of organic cosolvents concentrations higher than $10-20 \%$ (14). Therefore, effect of various organic solvents at concentrations of $20 \%$ (v/ v) on the enzyme was examined. The enzyme stabilities in organic solvents at $30^{\circ} \mathrm{C}$ for 1 and $24 \mathrm{~h}$ are shown (Table 5). The results revealed that Pseudomonas aeruginosa SRT9 lipase was stable for $24 \mathrm{~h}$ in organic solvents with the exception of $\mathrm{n}$ butanol and iso-propanol, suggesting alcohols with longer chain length have inhibitory effect. The lipase retains complete activity in n-hexane; even after treatment upto $48 \mathrm{~h}$. A significant degree of stabilization in the presence of organic solvent has been reported for this lipase than lipases obtained from Bacillus (43), Pseudomonas aeruginosa B 11 -1 (31).

\section{Thermo stability in organic solvents}

The thermal stability of the lipase was measured as remaining activity of the purified enzyme supplemented with $30 \%$ concentration of methanol, ethanol and n-hexane at $55^{\circ} \mathrm{C}$ and $70^{\circ} \mathrm{C}$ (Table 6). The results revealed that enzyme retained $100 \%$ activity in n-hexane for $30 \mathrm{~min}$ at $55^{\circ} \mathrm{C}$ and only $40 \%$ activity at $70^{\circ} \mathrm{C}$ for $15 \mathrm{~min}$. At $55^{\circ} \mathrm{C}$ the enzyme retained $99 \%$ activity in

Table 4. Effect of different metal ions on enzyme activity.

\begin{tabular}{ccc}
\hline Metal ions used & $\begin{array}{c}\text { Conc. used } \\
(\mathrm{mM})\end{array}$ & $\begin{array}{c}\text { Remaining activity } \\
(\%)\end{array}$ \\
\hline $\mathrm{Fe}^{2+}$ & 1.0 & 28.5 \\
$\mathrm{Ag}^{2+}$ & 1.0 & 30.5 \\
$\mathrm{Cu}^{2+}$ & 1.0 & 32.5 \\
$\mathrm{Hg}^{2+}$ & 1.0 & 65.5 \\
$\mathrm{~Pb}^{2+}$ & 1.0 & 63.5 \\
$\mathrm{Zn}^{2+}$ & 1.0 & 37.0 \\
$\mathrm{Ca}^{2+}$ & 1.0 & 107.0 \\
$\mathrm{Na}^{+}$ & 1.0 & 100.0 \\
\hline
\end{tabular}

Table 5. Stability of lipase in different solvents.

\begin{tabular}{cccc}
\hline Solvents & $\begin{array}{c}\text { Conc. used } \\
(\%)\end{array}$ & \multicolumn{2}{c}{$\begin{array}{c}\text { Remaining activity } \\
(\%)\end{array}$} \\
\cline { 3 - 4 } & & $1 \mathrm{~h}$ & $24 \mathrm{~h}$ \\
\hline Control & none & 100 & 100 \\
Methanol & 20 & 99.5 & 92.5 \\
Ethanol & 20 & 90.5 & 87.5 \\
iso-Propanol & 20 & 60.0 & 50.5 \\
Butanol & 20 & 40.0 & 38.0 \\
Acetone & 20 & 93.5 & 92.0 \\
n-Hexane & 20 & 99.5 & 99.0 \\
\hline
\end{tabular}


Table 6. Thermo stability of lipase in organic solvents.

\begin{tabular}{ccc}
\hline Organic solvent & \multicolumn{2}{c}{ Remaining activity $(\%)$} \\
\cline { 2 - 3 } & $55^{\circ} \mathrm{C}$ & $70^{\circ} \mathrm{C}$ \\
\hline Methanol & $99($ for $15 \mathrm{~min})$ & - \\
Ethanol & $75($ for $15 \mathrm{~min})$ & - \\
n-Hexane & $100($ for $30 \mathrm{~min})$ & 40 (for $15 \mathrm{~min})$ \\
\hline
\end{tabular}

- Not determined.

methanol and $75 \%$ in ethanol for $15 \mathrm{~min}$. However at $70^{\circ} \mathrm{C}$ the enzyme was very unstable in methanol and ethanol. The thermal instability of enzymes is a consequence of protein unfolding on exposure to high temperature however an improved thermal stability of enzymes in non-aqueous media has been documented (19). Results indicate that the enzyme is clearly stable in organic solvents at $55^{\circ} \mathrm{C}$ when compared to the lipases from Pseudomonas aeruginosa isolated from putrid mineral cutting oil (19).

\section{Substrate specificity}

The activities of the enzyme towards various triglycerides and p-nitrophenylesters were investigated (Fig. 7). With respect to the fatty acid specificity, the enzyme hydrolyzed triglycerides containing long chain fatty acids (C10-C16). Lipase showed highest activity towards triolein among the substrate examined. The enzyme also showed good activity towards trilaurin and tripalmitin with relative activities of $60 \%, 76 \%$ respectively. Short chain triglycerides were hydrolyzed poorly. The enzyme specificity towards lipids with fatty acid residues of C10-C16 chain length strongly suggest that the enzyme used in this study was a true lipase (18).

\section{Kinetic constants}

The Michaelis constant $(\mathrm{Km})$ was determined from the Lineweaver-Burk Plot for triolein as triglyceride and p-NPL and

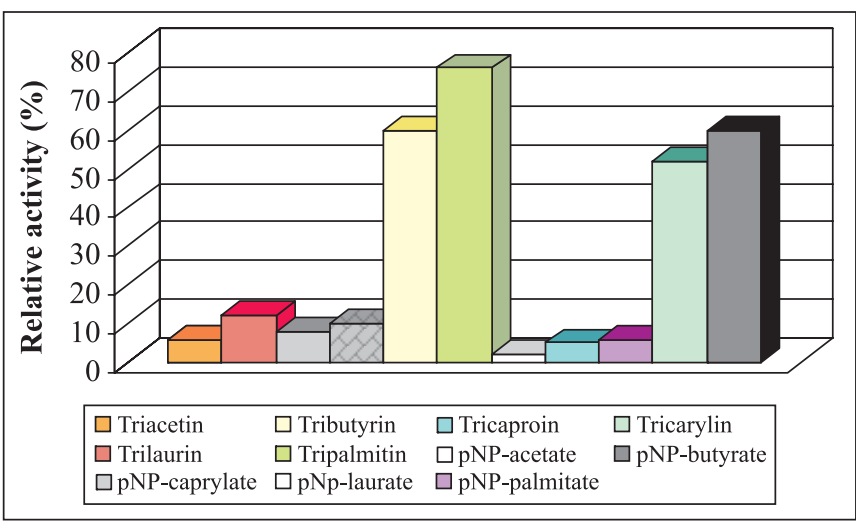

Figure 7. Hydrolytic activities of lipase with different substrates.

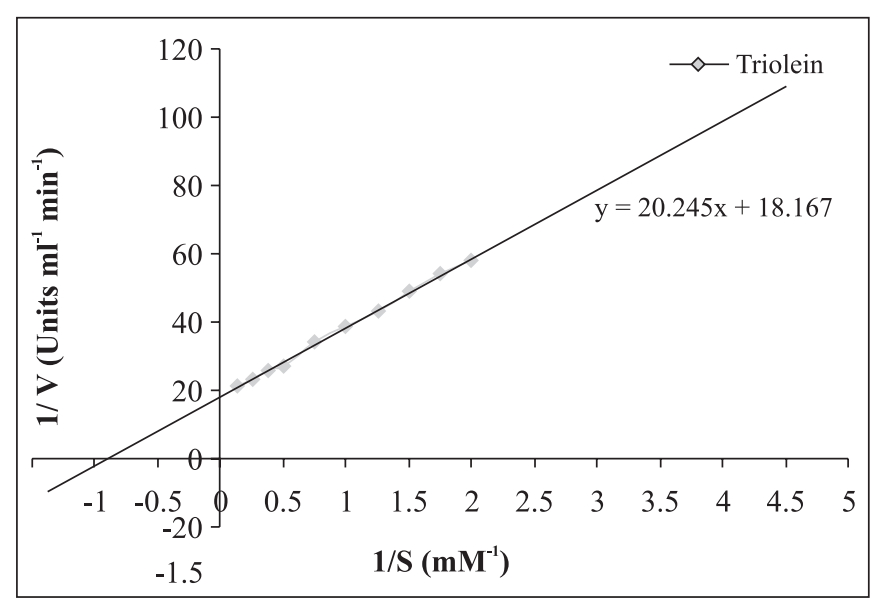

Figure 8. Lineweaver-Burk plot of Ps. aeruginosa lipases.

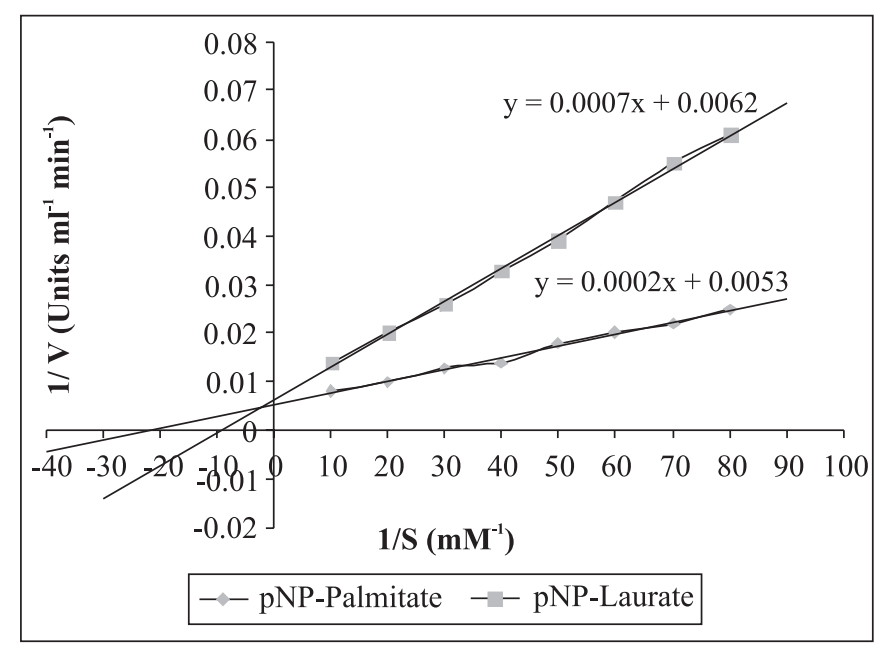

Figure 9. Lineweaver-Burk plot of Ps. aeruginosa lipase.

p-NPP as p-nitro phenyl esters (Fig. 8, 9). The Km value was determined to be $1.11 \mathrm{mM}$ with triolein as substrate; $\mathrm{Km}$ values of p-NPL and p-NPP were 0.11 and 0.037 respectively. The Vmax was determined as the reciprocal of the intercept. The Vmax values were calculated to be $0.055 \mathrm{mmol} / \mathrm{L} / \mathrm{min}$ for triolein and 161.3 and $188.6 \mathrm{mmol} / \mathrm{L} / \mathrm{min}$ respectively for $\mathrm{p}-\mathrm{NPL}$ and $\mathrm{p}-\mathrm{NPP}$. The lower apparent $\mathrm{Km}$ indicates that the partially purified lipase has higher affinity for $\mathrm{p}$ - NPP.

\section{CONCLUSION}

In the present work, partially purified lipase from Pseudomonas aeruginosa SRT 9 showed optimal activity in a wide range of temperatures and $\mathrm{pH}$ values. Moreover, because of its pronounced thermal stability as well as preservation of 
activity and stability in organic solvents, this enzyme could be of significant biotechnological potential, particularly in organo synthetic reactions carried out at higher temperatures. Future research will focus on structural characteristics of this enzyme. Moreover, studies on sequencing, subcloning and overexpression of these genes in E.coli may reveal the potential applications of this enzyme in future.

\section{ACKNOWLEDGMENT}

We are thankful to the Director, School of Life Sciences, SRTM University, for his valuable suggestions. Thanks are due to P. V. Ramana, Indian Institute of Chemical Technology, Hyderabad for technical assistance.

\section{RESUMO}

\section{Purificação e caracterização de uma lipase extracelular produzida por uma nova cepa - Pseudomonas aeruginosa SRT9}

Uma lipase extracelular foi isolada e purificada a partir de um caldo de cultura de Pseudomonas aeruginosa SRT9 até homogeneidade visível empregando-se precipitação com sulfato de amônia, seguida de técnicas cromatográficas em colunas de fenil sefarose CL-4B e Mono Q HR 5/5, obtendo-se um fator de purificação de 98 vezes, e atividade especifica de 12307,8 U/mg. Por SDS_PAGE, estimou-se que o peso molecular da lipase purificada é $29 \mathrm{kDa}$, com um ponto isoelétrico de 4,5 . A lipase apresentou atividade máxima em uma ampla faixa de temperatura e $\mathrm{pH}$, com ótimos a $55^{\circ} \mathrm{C}$ e $\mathrm{pH}$ 6,9. A lípase foi mais ativa sobre triacilglicerois de cadeia longa (C14-C16). A lipase foi fortemente inibida por EDTA, o que sugere que a enzima pode ser uma metaloproteína. SDS e íons metálicos, como $\mathrm{Hg}^{2+}, \mathrm{Zn}^{2+}, \mathrm{Cu}^{2+}$, $\mathrm{Ag}^{2+} \mathrm{e} \mathrm{Fe}^{2+}$, diminuíram marcadamente a atividade da lipase. Sua grande estabilidade e atividade em solventes organicos sugerem que esta lípase pode ser uma excelente ferramenta tecnológica com várias aplicações como reações organosintéticas e preparação de produtos farmacêuticos enantiomericamente puros. Os valores de Km e Vmax para a enzima purificada na hidrólise de trioleina foram $1,11 \mathrm{mmol} / \mathrm{L} \mathrm{e} 0,05 \mathrm{mmol} / \mathrm{L} / \mathrm{min}$, respectivamente.

Palavras-chave: Pseudomonas aeruginosa SRT9, lipase extracelular, purificação, constante de Michaelis

\section{REFERENCES}

1. Abbas, H.; Hiol, A.; Deyris, V.; Comeau, L.C. (2002). Isolation and characterization of an extracellular lipase from Mucor sp. Strain isolated from palm fruit. Enz. Microb. Technol. 31, 968-975.

2. Abramic, M.; Lescic, I.; Korica, T.; Vitale, L.; Saenger, W.; Pigac, J. (1999). Purification and properties of extracellular lipase from Streptomyces rimosus. Enz.Microb.Technol. 25, 522-529.
3. Aires-Barros, M.R.; Taipa, M.A.; Cabral, J.M.S. (1994). Isolation and purification of lipase. In: P. Wooley Peterson, S. B (eds) Lipase, their structure, biochemistry and application. Cambridge University Press, p. 243-70.

4. Altschul, S.F.; Madden, T.L.; Schaffer, A.A.; Zhang, J.; Zhang, Z.; Miller, W.; Lipman, D.J. (2007). Gapped BLAST and PSI-BLAST: a new generation of protein database search programs. Nucleic Acids Research. 25, 3389-3402.

5. Balcao, V.M.; Paiva, A.L.; Malcata, F.X. (1996). Review: Bioreactors with immobilized lipase: State of the art. Enz. Microb. Technol. 18, 392-416.

6. Castro-Ochoa, L.D.; Rodriguez-Gomez, C.; Valerio-Aifaro, G.; Ros, R.O. (2005). Screening, purification and characterization of the thermoalkalophilic lipase produced by Bacillus thermoleovorans CCR11. Enz. Microb. Technol. 37, 648-654.

7. Chartrain, M.; Katz, L.; Marcin, C.; Thien, M.; Smith, S.; Fisher, E.; Goklen, K.; Salmon, P.; Brix, T.; Price, K.; Greasham, R. (1993). Purification and characterization of a novel bioconverting lipase from Pseudomonas aeruginosa MB 5001. Enz. Microb. Technol. $15,575-580$.

8. Dong, H.; Gao, S.; Han, S.P.; Cao, S.G. (1999). Purification and characterization of a Pseudomonas sp. lipase and its properties in non-aqueous media. Biotechnol Appl. Biochem. 30, 251-256.

9. Fox, P.F.; Stepanaik, L. (1983). Isolation and some properties of extracellular heat stable from Pseudomonas fluorescens strain AFT 36. J. Dairy Research. 50, 77-89.

10. Gabrial, O. (1971). Locating enzymes on gels. In: William Jackoby (ed). Methods Enzymol., Academic Press, New York.

11. Gilbert, E.J.; Cornish, A.; Jones, C.W. (1991). Purification and properties of extracellular lipase from Pseudomonas aeruginosa EF2. J. General Microbiol. 137, 2223-2229.

12. Gitlesen, T.; Bauer, M.; Adlercreutz, P. (1997). Adsorption of lipase on polypropylene powder. Biochem. Biophys. Acta. 1345, 188-196.

13. Godris, H.L.; Ampe, G.; Feyten, P.M.; Fouwe, B.L.; Guffens, W.M.; Van Cauwecebergh, S.M.; Tobback, P.P. (1987). Lipase catalyzed ester exchange reaction in organic media with control humidity. Biotechnol. Bioengg. 30, 258-266.

14. Gupta, M.; Batra, R.; Tyagi, R.; Sharma, A. (1997). Polarity index, the guiding solvents parameter for enzyme stability in aqueousorganic co-solvents mixtures. Biotechnol. Prog. 13, 284-288.

15. Hiol, A.; Jonzo, M.D.; Rugani, N.; Druet, D.; Sarda, L.; Comeau, L.C. (2000). Purification and characterization of an extracellular lipase from thermophilic Rhizopus oryzae strain isolated from palm fruit. Enz. Microb. Technol. 26, 421-430.

16. Jaeger, K.E.; Eggert, T. (2002). Lipases for biotechnology. Cur. opi. Biotechnol. 13, 390-397.

17. Jaeger, K.E.; Liebton, K.; Zonta, A.; Schimossek, K.; Reetz, M.T. (1996). Biotechnological applications of Pseudomonas aeruginosa lipase efficient kinetic resolution of amines alcohols. Appl. Microbial. Biotechnol. 46, 99-105.

18. Janaina, N.P.; Juliana, A.B.C.; Glucia, M.P. (2006). Characterization of alkaline lipase from Fusarium oxysporum and the effect of different surfactants and detergents on the enzyme activity. Brazilian J. Microbiol. 37, 505-509.

19. Karadzic, I.; Masui, A.; Zivkovic, L.I.; Fujiware, N. (2006). Purification and characterization of an alkaline lipase from Pseudomonas aeruginosa isolated from putrid mineral cutting oil as component of metal working fluid. J. Biosci. Bioengg. 102, 82-89.

20. Kim, M.H.; Kim, H.K.; Lee, J.K.; Park, S.Y.; Oh, T.K. (2000). Thermostable lipase of Bacillus stearothermophilus: High-level production, purification and calcium dependent thermostability. Biosci. Biotechnol. Biochem. 64, 280-286.

21. Kirchner, G.; Scollar, M.P.; Klibanov, A.M. (1985). Resolution of racemic mixtures via lipase catalysis in organic solvents. $J$. Am Chem. Soc. 107, 7072-76. 
22. Kordel, M.; Hofmann, B.; Schomburg, D.; Schmid, R.D. (1991). Extracellular lipase of Pseudomonas sp. Strain ATCC 21808: purification, characterization, crystallization and preliminary $\mathrm{X}$ ray diffraction data. J. Bacteriol. 173, 4836-4841.

23. Laemmli, U. K. (1970). Cleavage of structural proteins during the assembly of the head of the bacteriophage T4. Nature. 227, 680685 .

24. Liebeton, K.; Zacharias, A.; Jaeger, K.E. (2001). Disulfide bond in Pseudomonas aeruginosa lipase stabilizes the structure but is not required for interaction with its foldase. J. Bacteriol. 183, 597-603.

25. Lin, S.F.; Chiou, C.M.; Yeh, C.M.; and Tsai, Y.C. (1996). Purification and partial characterization of an alkaline lipase from Pseudomonas pseudoalcaligenes F-111. Appl. Env. Microbiol. 62, 1093-1095.

26. Lowry, O.H.; Rosebrough, N.J.; Farr, A.L.; Randall, R.J. (1951). Protein measurement with the folin phenol reagent. J. Biol. Chem. 193, 265-275.

27. Machido, G.A.; Park, Y.K.; Pastore, G.M. (1997). Partial purification characterization of an extracellular lipase from a newly isolated strain of Geotrichum sp. Rev. Microbiol. 28, 90-95.

28. Macrae, A.R. (1983). Lipase catalyzed interesterfication of oils and fats. J. Am. oil Chem. Soc. 60, 291-294.

29. Macrae, A.R.; Hammond, A.R. (1985). Present and future applications of lipases. Biotechnol. Genet. Eng. Rev. 3, 193-217.

30. Muira, T.; Yamane, T. (1997). Screening for fungi that have lipolytic and acidolytic activities in biomass support particles. Biosci. Biotechnol. Biochem. 611, 1252-57.

31. Ogino, H.; Ishikawa, H. (2001). Enzymes which are stable in the presence of organic solvents. J. Biosci. Bioengg. 91,109-116.

32. Raja Noor Zaliha, R.A.R.; Syarul, N.B.; Abu, B.S.; Mahiran, B. (2006). S5 lipase: An organic solvent enzyme. J. Microbiol. 44, 583-590.

33. Saeed, H.M.; Zaghloul, T.I.; Khalil, A.I.; Abdelbaeth, M.T. (2005). Purification and characterization of two extracellular lipases from
Pseudomonas aeruginosa Ps -x. Polish J. Microbiol. 54, 233-240.

34. Sarda, L.; Desnuelles, P. (1958). Action da la lipase pancreatique sur les esters in emulsion. Bichem. Biophys. Acta. 30, 513-21.

35. Saxena, R.K.; Sheoran, A.; Giri, B.; Dandson, S.W. (2003). Purification strategic for microbial lipase. J. Microbiological Methods. 52, 1-18.

36. Sharon, C.; Furugoh, S.; Yamakido, T.; Ogawa, H.; Kato, Y. (1998). Purification and characterization of a lipase from Pseudomonas aeruginosa KKA- 5 and its roll in castor oil hydrolysis. J. Microbiol. Biotechnol. 20, 304-307.

37. Sheldon, R.A. (2007). Enzyme Immobilization: The quest for optimum performance. Adv. Synth. Catal. 349, 1289-1307.

38. Sjtajer, H.; Maliszewska, I.; Wierczorek, J. (1988). Production of exogenous lipase by bacteria, fungi and actinomycetes. Enz. Microb. Technol. 10, 492-97.

39. Stocklein, W.; Sjtajer, H.; Menge, V.; Schmid, R.D. (1993). Purification and properties of lipase from Penicillium expansum. Biochem. Biophys. Acta. 1168, 181-89.

40. Stuer, W.; Jaeger, K.E.; Winkler, U.K. (1986). Purification of extracellular lipase from Pseudomonas aeruginosa. J. Bacteriol. 168, 1070-1074.

41. Sugiura, M. (1984). Bacterial lipases. In: B. Borgstrom an H.L. Brockman (eds) Lipase. Elsevier, Amsterdam.

42. Suzuki, T.; Mushiga, Y.; Yamane, T.; Shimizu, S. (1988). Mass production of lipase by fed-batch culture of Pseudomonas fluorescens. Appl. Microbiol Biotechnol. 27, 417-422.

43. Torres, S.; Castro, G. (2004). Non- aqueous biocatalysis in homogenous systems. Food Technol. Biotechnol. 42, 271-277.

44. Verger, R. (1984). Pancreatic lipase. In B. Borgstrom and H.L. Brockman (ed.), Lipase. Elsever, Amsterdam.

45. Winkler, U.K.; Stuckmann, M. (1979). Glycogen hyaluronate, and some other polysaccharides greatly enhance the formation of exolipase by Serratia marcescens. J. Bacteriol. 139, 663-670. 